\title{
Teaching Techniques Implemented by Preschool Teachers in English Early Literacy Instructional Practices: A Case Study
}

\author{
Farah Munirah Roslan Johari, Faridah Yunus \\ Faculty of Education, Universiti Kebangsaan Malaysia, Bangi, Selangor, Malaysia \\ Email: faridahyunus@ukm.edu.my,faridahyunus@gmail.com
}

How to cite this paper: Johari, F. M. R., \& Yunus, F. (2021). Teaching Techniques Implemented by Preschool Teachers in English Early Literacy Instructional Practices: A Case Study. Creative Education, 12, 21-30.

https://doi.org/10.4236/ce.2021.121002

Received: November 11, 2020

Accepted: December 28, 2020

Published: December 31, 2020

Copyright $\odot 2021$ by author(s) and Scientific Research Publishing Inc. This work is licensed under the Creative Commons Attribution International License (CC BY 4.0).

http://creativecommons.org/licenses/by/4.0/

\begin{abstract}
This multiple case study aims to address preschool teachers' practices implemented in early literacy instruction specifically in terms of the teaching techniques used by teachers during English early literacy classroom instruction. Four in-service teachers from three types of preschool which are private, government and non-government organizations located in a suburban area, were selected as the study's participants. Data collections involved throughout the study were field notes, checklist, video recording and classroom observations. A teaching technique checklist is used as an instrument to analyze types of teaching techniques implemented by teachers. Results show that the preschool teachers only implement general teaching techniques and often do not implement specialist teaching techniques during English literacy instruction. The most common teaching techniques implemented by the teachers during English literacy instruction are: 1) demonstrating, 2) describing, 3) encouraging, praising, and helping, 4) facilitating, 5) listening, 6) positioning people, 7) questioning, 8) recalling, 9) singing and 10) telling and instructing. Generalization may not be fair at this stage, but the findings may reflect the need to provide appropriate training for preschool teachers. Larger samples are crucial to understand the scale of the teaching practice being appropriate or not for effective English language literacy instruction.
\end{abstract}

\section{Keywords}

Early Literacy, Teaching Techniques, Literacy Skills, Preschool

\section{Introduction}

The government of Malaysia's realization and awareness of the importance of early literacy teaching and learning is clearly demonstrated in the Malaysia Education 
Blueprint 2013-2025 in which it is highlighted that enhancing and ensuring students' proficiency in both the Malay and English language are of priority and are stated as the second shift out of eleven shifts of transformation listed in the blueprint. Throughout the years, the Malaysian government has shown efforts towards enhancing skills students' literacy which has started even before the 2013-2025 blueprint was released. In 2006, the government launched an intervention program that focuses specifically on enhancing students' reading and writing skills. This program is called Kelas Intervensi Awal Membaca dan Menulis (KIA2M) or Reading and Writing Early Intervention Class. This program was later replaced with another program called LINUS (Literacy and Numeracy Screening) in the year 2010 which focuses on both literacy and numeracy skills. However, both KIA2M and LINUS only focus on literacy skills in the Malay language rather than the English language. In the year 2013, it was subsequently upgraded to LINUS 2.0 focusing on literacy skills of both the Malay and English language.

Although the government's efforts towards ensuring that all Malaysian children acquire basic literacy skills are commendable, these programs only focus on children who are entering formal education in primary school at the age of seven. Literacy learning should begin at an earlier age before a child enters primary school. In fact, the development of a child's early literacy skills begins at birth until he or she enters school (Wildová \& Kropáčková, 2015). Therefore, it is of utmost importance for preschool teachers to ensure that children's literacy experience is enriched (Johari \& Yunus, 2019). Preschool teachers play a significant role in developing children's literacy development which will later impact their success in school (Dennis \& Horn, 2011). In Malaysia, preschool teachers are teaching children with a diverse ethnic background with many who are from homes where English is not the first language. Therefore, it may be a challenge for Malaysian preschool teachers to teach the language because they need to implement a variety of instructional methods in order to meet the diverse needs of Malaysian children (Asmawi \& SeyedHendi, 2016). This suggests that preschool teachers need to apply various teaching techniques, not just focusing on one or a few techniques when teaching children English literacy. Studies have shown that there is poor implementation of English teaching and learning by preschool teachers in Malaysia (Asmawi \& SyedHendi, 2016; 2018). However, more research needs to be done regarding this issue as studies on English early literacy instruction in Malaysian preschool context are scarce. Therefore, this paper aims to investigate the practices of English literacy instruction in Malaysian preschool in terms of the teaching techniques implemented by preschool teachers when teaching English literacy.

\section{Literature Review}

\subsection{Literacy Defined}

In today's environment, it is important to introduce and expose children to literacy learning at an early age as it has become an important foundation for their 
learning and development. Literacy is not just simply a set of skills necessary to be learned and mastered. It is more complex than that. In fact, not only is it a complex and social skill but also "the literate demands of the world keep changing with exponential acceleration" as the boundaries and conventions between written and spoken words have been eradicated by the advancement of technology (Johnston \& Costello, 2005). Due to the rapid advancement in technological development, the meaning and conventions of literacy may have changed overtime. Literacy is not only limited to writing, reading, speaking, and listening but has progressed into technology related skills such as computer and digital, skills. In fact, technology can be incorporated into classroom instruction to aid in literacy teaching and learning. Fox (2014) noted that "technology may be effective for struggling readers and writers who are considered to be digital natives" (p. 2). Because literate demands are changing so rapidly and probably will keep changing in the future, it is critical for preschool teachers to prepare children to meet such demands when they become older.

If children's interest in literacy can be inculcated early starting from when they were introduced to print supported by developmentally appropriate practices especially to those who are facing literacy difficulties, it can help boost their confidence in literacy learning and advocate successful learning (Fern \& Jiar, 2014). Moreover, children who are introduced to literacy learning at an earlier age are likely perform better in school compared to children who started late. This suggests that children who could not read or write before entering formal education in primary school will have more difficulties and challenges in learning and coping at school. However, early exposure to literacy would be considered meaningless if children's literacy experience is ineffective and insufficient. Therefore, it is critical that children receive an enriched literacy experience through effective and developmentally appropriate teaching practices.

\subsection{Teachers' Role}

Preschool teachers play a vital role in the shaping of children's early literacy development. The way teachers execute and implement teaching practices greatly influences children's development in early literacy skills which will later impact them either positively or negatively depending on how teachers deliver and execute literacy instructional practices. This means that children who are exposed to best literacy practices are more likely to excel in learning compared to those who are not. In fact, Majzub (2013) mentioned that children's development and learning are influenced by their own positive and negative experiences which will impact them for a long time.

Despite preschool teachers being familiar with the idea that children learn through play, this notion is not consistently translated into practice (Asmawi \& SyedHendi, 2018). As opposed to the ideal learning environment in the preschool setting which should involve active learning and child-directed learning; passive teacher-directed learning which involves approaches that focuses on 
memorization and "chalk and talk" methods are believed to be still in implementation in Malaysian preschools (Qin \& Nor, 2018). Because literacy learning requires interaction and experiences, instructional practices, which focuses on memorization and rote learning will only provide less opportunities for children to practice the skill. Also, such methods will not promote children's engagement and interest in literacy learning. Similarly, Baroody and Diamond (2016) highlighted that when children are interested and engaged during literacy learning they are more likely to have more opportunities to practice the skills. Children who have poor English literacy skills do not necessarily mean that they are not able to learn or acquire the skills. Similarly, Abdul Rahman and Maaarof (2015) stated that students who fail in the English subject does not mean that they are less able than their peers, however, it is because they are not engaged during classroom activities. Therefore, teachers should be both creative and innovative to attract children's attention during English lessons (Misbah et al., 2017) and implement an appropriate teaching techniques and methods that can advocate children's engagement.

Regarding teacher's early literacy instruction, Pray (2010) believes that most of the local English Second language (ESL) teachers have little experience when it comes to teaching English language learners (ELL), learning a second language as well as working with learners from a diverse background in terms both of cultural and linguistic. This suggests that most local teachers teach English when in fact, they themselves have little knowledge regarding the language as well as insufficient experience teaching it. Because Malaysia is rich in culture and ethnicity with its people coming from diverse backgrounds, teachers may find it even more difficult to teach English to such diverse population of children even more so when they themselves do not how to teach the language.

Moreover, Tang et al. (2011) reported in their study that in Malaysia, most preschool programs are not required to employ teachers "who meet even the most basic professional requirements" (p. 98). This suggests that most preschool teachers in Malaysia do not need the basic professional requirements and qualifications in the field or early childhood education (ECE) to teach in preschools. In fact, there are many teachers who do not have early childhood education background, let alone English education background, teaching in preschools. Foong et al. (2018) reported that teachers teaching in public preschools that are managed by the Ministry of Education are qualified and trained, however, private preschools do not have qualified teachers because of inadequate expenditure to employ teachers with expertise in ECE. As a result, children will not receive quality education as they should be. Therefore, it is important to ensure that preschool teachers are developed, trained, and equipped professionally in both early childhood education and early literacy instruction. Moreover, it is also it is important for beginner teachers to be given quality and proper training ( $\mathrm{Md}$. Yunus et al., 2010) before they start teaching in preschools and such training should be continuously carried out as they begin to teach so that they can con- 
tinue to develop professionally and acquire the expertise in literacy instruction.

\section{Methodology}

\subsection{Samples}

The current study employed a qualitative research design and adopted a multiple case study. Creswell (2012) mentioned that "multiple cases are described and compared to provide insight into an issue" (p. 465). For better understanding of the selected cases, information was collected and gathered using several sources which included field notes, video recording, classroom observations and a teaching technique checklist. The present study used purposive sampling as a sampling method. Three types of preschools were selected as the research sites for the present study. The selection of the three preschools was based on three factors. First, the preschools are of three different types which are private, government and non-government organizations. Second, the preschools were in a suburban area, and third, the preschools' curriculum is subject-oriented.

Four in-service preschool teachers from the three different types of preschools were selected to participate in the current study. Teacher A teaches in a private preschool and has been involved and serving in the field of early childhood education for about 20 years whereas teacher $\mathrm{B}$ teaches in a government preschool and has been teaching for three years. Teacher $\mathrm{C}$ teaches in an NGO pre-school and has been teaching in the present preschool for less than a year. Teacher D is also teaching in the same non-government organization preschool as teacher D and is relatively new in the field. She has been teaching in the present preschool for less than six months.

\subsection{Data Collection}

Classroom observations were conducted for all three preschools. Each teacher was observed during their English lessons and the observations were video recorded for reference. The researcher also took field notes of each observation session and took pictures of the teaching aids and materials used during the lessons. The purpose of the field notes was to record and gather important data and information that reflects teachers' classroom instruction practices specifically in terms of the teaching techniques implemented during English lessons. A teaching technique checklist designed based on Mac Naughton's and William's (2009) teaching techniques which were extracted from their book titled Teaching Young Children: Choices in Theory and Practice Second Edition, was used. The checklist is divided into two main types of teaching techniques which are the general teaching technique and the specialist technique. The general teaching technique consists of 15 techniques and the specialist teaching technique consists of 12 techniques. The checklist was reviewed and validated by experts of the field. Based on experts' comments and suggestions, some items were advised to be rephrased and certain words were advised to be changed for precise wording. 
After reviewing teachers' practices based on the field notes and video records from the classroom observations, the researcher checked the items from the checklist accordingly. The checklist was checked based on the criteria of the teaching techniques listed in the checklist.

\section{Results}

\section{Teaching Techniques}

Table 1 displays the teaching techniques implemented by preschool teachers

Table 1. Teaching techniques implemented by teachers.

\begin{tabular}{|c|c|c|c|c|c|}
\hline \multirow{2}{*}{ Type/Category } & \multirow{2}{*}{ Teaching Technique } & \multicolumn{4}{|c|}{ Teacher } \\
\hline & & A & B & $\mathrm{C}$ & $\mathrm{D}$ \\
\hline \multirow{15}{*}{$\begin{array}{c}\text { General Teaching } \\
\text { Technique }\end{array}$} & Demonstrating & $\mathrm{x}$ & & $\mathrm{x}$ & $\mathrm{x}$ \\
\hline & Describing & $\mathrm{x}$ & & $\mathrm{x}$ & $\mathrm{x}$ \\
\hline & Encouraging, praising, and helping & $\mathrm{x}$ & $\mathrm{x}$ & $\mathrm{x}$ & $\mathrm{x}$ \\
\hline & Facilitating & $\mathrm{x}$ & $\mathrm{x}$ & $\mathrm{x}$ & $\mathrm{x}$ \\
\hline & Feedback & & & & \\
\hline & Grouping & & & & \\
\hline & Listening & $\mathrm{x}$ & $\mathrm{x}$ & $\mathrm{x}$ & $\mathrm{x}$ \\
\hline & Modelling & & & & \\
\hline & Positioning people & $\mathrm{x}$ & $\mathrm{x}$ & $\mathrm{x}$ & $\mathrm{x}$ \\
\hline & Questioning & $\mathrm{x}$ & $\mathrm{x}$ & $\mathrm{x}$ & $\mathrm{x}$ \\
\hline & Reading & $\mathrm{x}$ & & & \\
\hline & Recalling & $\mathrm{x}$ & $\mathrm{x}$ & $\mathrm{x}$ & $\mathrm{x}$ \\
\hline & Singing & $\mathrm{x}$ & $\mathrm{x}$ & $\mathrm{x}$ & $\mathrm{x}$ \\
\hline & Suggesting & & & & \\
\hline & Telling and instructing & $\mathrm{x}$ & $\mathrm{x}$ & $\mathrm{x}$ & $\mathrm{x}$ \\
\hline \multirow{12}{*}{$\begin{array}{c}\text { Specialist Teaching } \\
\text { Technique }\end{array}$} & Co-constructing & & & & \\
\hline & Community building & & & & \\
\hline & Decolonizing & & & & \\
\hline & Deconstructing & & & & \\
\hline & Democratizing & & & & \\
\hline & Documenting & & & & \\
\hline & Empowering & & & & \\
\hline & Philosophizing & & & & \\
\hline & Problem-solving & & & & \\
\hline & Reinforcing & & & & \\
\hline & Scaffolding & & & & \\
\hline & Task analysis & & & & \\
\hline
\end{tabular}


during English literacy instruction. Results show that the teachers do implement a variety of teaching techniques, however, they are focused mainly on the general teaching technique and not the specialist teaching technique. The general teaching technique may be quite common compared to the specialist teaching technique which explores beyond the familiar techniques and requires higher order thinking skills. Based on the results obtained from classroom observation, it is found that the teachers implement similar teaching techniques which are 1) demonstrating, 2) describing, 3) encouraging, praising and helping, 4) facilitating, 5) listening, 6) positioning people, 7) questioning, 8) recalling, 9) singing and 10) telling and instructing.

\section{Discussion}

Demonstrating; describing; encouraging, praising, and helping; facilitating; feedback; grouping; listening; modelling; positioning people; questioning; reading; recalling; singing; suggesting; and telling and instructing are the general or non-specialist techniques. These techniques are usually inclined towards one-way communication, teacher-directed learning, passive-leaning, and lack input from children. It is not wrong to practice these techniques because young children need some specific guidance and examples in their daily routines. However, practicing only these techniques on day-to-day basis could harm the children in such a way that their thinking abilities, independence, and the active-learning process which lead to higher order thinking skills may suppressed.

In the current study, teachers' practices in English literacy instructions are reflected through their implementation of teaching techniques during classroom instruction. The findings showed that all the teachers implement similar techniques such as demonstrating, describing, facilitating, and listening. Although the teaching techniques used by the teachers may seem basic and simple, however, it can be powerful in developing and shaping children's learning whereby they act as a foundation on which the complex specialist techniques are built (Mac Naughton \& Williams, 2009). Therefore, though they are basic and not as complex as specialist techniques, general teaching techniques are still essential in children's learning and development.

Based on the findings from observations, it is found that the preschool teachers involved only focused on general teaching techniques and not on the specialist teaching techniques. This may be because the specialist teaching techniques may require teachers to explore and develop children's higher order thinking skills. As most of the teachers participating in the study are beginner teachers who are relatively new in teaching and are may not yet have a sufficient experience to implement such techniques, it is understandable that they did not implement such techniques. Moreover, these young beginner teachers are also not from an early childhood education background.

However, it is also important to note that many teachers teaching in the field of early childhood education in Malaysia tend to consist of young in experience 
teachers especially in private preschools and early childhood education centers. Foong et al. (2018) revealed in their study that there is a large proportion of teachers from private sector of early childcare and education in Malaysia who are "young, under qualified, inexperienced and underpaid" (p. 127). However, this does not necessarily mean there are no experienced or senior teachers in Malaysian preschools. These young teachers do not only lack experience, but they also do not have the right qualifications to teach English literacy to young learners. This may also be one of the factors why they do not implement specialist techniques as it may be quite challenging for them.

Though the current study involved young and beginner teachers, one of the teachers observed in the study has been serving in the field for about 20 years and yet the results show that the teaching techniques implemented by the teacher are almost identical to those of the beginner teachers. Based on observations, this teacher also did not implement specialist teaching techniques during English literacy instruction. As noted earlier, it may be because specialist teaching techniques require teachers to develop children's higher order thinking skills (HOTS) through philosophizing and introducing them to political ideas and issues through decolonizing. Even at preschool level, HOTS should be embedded in the teaching and learning process to develop children mentally and physically (Masnan et al., 2018). As cited in Nachiappan et al. (2018), A. Rahman, Jamaludin and Zamri stated that most teachers do not give emphasis on children's thinking skills when they teach. Nachiappan et al. (2018) further stated that one of the reasons why teachers do not emphasize on HOTS is because some teachers believe that children should first acquire and master the concepts of a certain subject before they should be encouraged to think.

\section{Conclusion}

This paper aimed at identifying the existing techniques being practiced by the teachers at preschool levels of academic-oriented atmosphere. We suspected that techniques of teaching would be compromised and that the use of non-specialist techniques was favored when scores are being the center of assessment. The specialist techniques are difficult to practice undoubtedly, but through dedicated training, teachers will master them. Highlight of the findings suggests that more careful observations need to be carried out to understand the needs for more rigorous trainings for teachers across the country in the future. We know at this stage that it is quite common for teachers to resort to non-specialist techniques, but we also need to understand more about why they do it and how to shift to more specialist techniques. Deeper understanding on the existing belief, knowledge, and readiness of the teachers could be another step before development of training modules; especially for senior teachers who would resist change.

All children are entitled to a quality and enriched literacy teaching and learning experience. Understanding the teaching techniques and instructional practices of preschool teachers in English literacy instruction is crucial to plan and 
design appropriate intervention programs to support and train teachers regarding efficient and developmentally appropriate literacy teaching and learning. Intervention in preschool is likely to be a more effective and successful remediation when it is provided earlier rather than later. Appropriate and efficient practices in the teaching and learning of English literacy that utilizes effective teaching techniques at an early age are fundamental to ensure children receive an enriched literacy experience. If preschool teachers were to implement poor teaching practices, it will negatively affect children's English literacy development in later years. Therefore, it is critical that preschool teachers equip themselves with sufficient content knowledge and a repertoire of effective and efficient teaching techniques and strategies.

\section{Acknowledgements}

The data displayed in the paper is part of a mini thesis project undertook by the main author for her master's degree program; we thank the teachers from the centers who participated in this study for their cooperation.

\section{Conflicts of Interest}

The authors declare no conflicts of interest regarding the publication of this paper.

\section{References}

Abdul Rahman, N. A., \& Maarof, N. (2015). The Relationship between Language Strategies and Students' Motivation in Learning English as a Second Language. Jurnal Teknikal Sosial Sains, 1, 1-18.

Asmawi, A., \& SeyedHendi, N. (2016). Preschool English Teachers' Practices and Early Literacy Instruction: A Multiple Case Study. Asian Education Studies, 1, 1-3. https://doi.org/10.20849/aes.v1i2.72

Asmawi, A., \& SeyedHendi, N. (2018). Preschool English Teachers' Practices and Early Literacy Instruction: Montessori vs International Preschool Curriculum. Malaysian Online Journal of Educational Sciences, 6, 29-36.

Baroody, A. E., \& Diamond, K. E. (2016). Associations among Preschool Children's Classroom Literacy Environment, Interest and Engagement in Literacy Activities, and Early Reading Skills. Journal of Early Childhood Research, 14, 146-162. https://doi.org/10.1177/1476718X14529280

Creswell, J. W. (2012). Educational Research: Planning, Conducting, and Evaluating Quantitative and Qualitative Research. London: Pearson Education.

Dennis, L. R., \& Horn, E. (2011). Strategies for Supporting Early Literacy Development. Young Exceptional Children, 14, 29-40. https://doi.org/10.1177/1096250611420553

Fern, N. P., \& Jiar, Y. K. (2014). Preschool Teachers' Beliefs and Practices on Early Literacy Instruction. Sains Humanika, 2, 139-146.

Fox, L. C. (2014). Effects of Technology on Literacy Skills and Motivation to Read and Write (p. 522). Education and Human Development Master's Theses.

Johnston, P., \& Costello, P. (2005). Principles for Literacy Assessment. Reading Research Quarterly, 40, 256-267. https://doi.org/10.1598/RRQ.40.2.6 
Mac Naughton, G., \& Williams, G. (2009). Teaching Young Children: Choices in Theory and Practice. New York: Open University Press.

Majzub, R. M. (2013). Critical Issues in Preschool Education in Malaysia. In Proceedings of the 4th International Conference of Education and Educational Technologies (pp. 150-155).

Masnan, H., Josin, E. H., Zain, A., \& Zainudin, N. A. S. (2018). Environmental Preschool Education Module Based on Higher Order Thinking Skills (HOTS). The Turkish Online Journal of Design, Art and Communication, 1442-1449.

Md. Yunus, M. M., Hashim, H., Ishak, N. M., \& Mahamod, Z. (2010). Understanding TESL Pre-Service Teachers' Teaching Experience and Challenges via Post-Practicum Reflection Forms. Procedia Social and Behavioral Sciences, 9, 722-728.

https://doi.org/10.1016/j.sbspro.2010.12.224

Misbah, N. H., Mohamad, M., Yunus, M. M., \& Ya'acob, A. (2017). Identifying the Factors Contributing to Students' Difficulties in the English Language Learning. Creative Education, 8, 1999-2008. https://doi.org/10.4236/ce.2017.813136

Nachiappan, S., Osman, R., Masnan, A. H., Mustafa, M. C., Hussein, H., Suffian, S., Sehgar, S. C., Sukri, N. A., \& Kumar, A. (2018). Teacher's View on the Role-Play of the Authorities in the Implementation of Higher Order Thinking Skills (HOTs) in Preschool. International Journal of Academic Research in Business and Social Sciences, 8 , 194-201. https://doi.org/10.6007/IJARBSS/v8-i4/4007

Pray, L. (2010). ESL Teacher Education Abroad and at Home: A Cautionary Tale. The Teacher Educator, 45, 216-229. https://doi.org/10.1080/08878730.2010.488099

Qin, T. Y., \& Nor, M. M. (2018). Exploring Issues on Teaching and Learning in Malaysian Private Preschools. Malaysian Online Journal of Educational Management (MOJEM), 6, 67-82. https://doi.org/10.22452/mojem.vol6no2.4

Roslan Johari, F. M., \& Yunus, F. (2019). Preschool Teachers' Practices in English Early Literacy Instruction: A Case Study. Creative Education, 10, 2701-2710. https://doi.org/10.4236/ce.2019.1012196

Tang, K. N., Hashim, N. H., \& Yunus, H. M. (2011). Preschool Teachers' Quality in Lesson Preparation and Implementation. The International Journal of Learning, 17, 89-105.

Wildová, R., \& Kropáčková, J. (2015). Early Childhood Pre-Reading Literacy Development. Procedia Social and Behavioral Sciences, 191, 878-883.

https://doi.org/10.1016/j.sbspro.2015.04.418 